\author{
Silvio A. Namendys-Silva \\ Marisol Hernández-Garay
}

\section{Hydrocortisone therapy for patients with H1N1 influenza $A$ infection}

Accepted: 3 December 2009

Published online: 30 March 2010

(C) Copyright jointly held by Springer and ESICM 2010

The author's reply to this comment is available at:

doi:10.1007/s00134-010-1816-6.

Dear editor: We read with interest Quispe-Laime and colleagues' work [1] which described the clinical presentation of 13 consecutive patients and their response to combination high-dose oseltamivir and prolonged low-to moderate dose corticosteroid treatment.

A systematic review [2] suggested that prolonged low-dose corticosteroid therapy decreases mortality and recommended treating adult patients with vasopressor-dependent septic shock. Annane and colleagues [3] had shown that a 7-day treatment with the combination of low doses of hydrocortisone and 9- $\alpha$-fludrocortisone significantly improved survival at day 28 and at Intensive Care Unit and hospital discharge, and reduced the duration of mechanical ventilation in patients with septic shock associated early acute respiratory distress syndrome (ARDS) and a weak cortisol response to corticotropin without inducing serious adverse events. There is insufficient evidence to support steroid administration for sepsis with shock, regardless of a patient's response to corticotropin testing [4]. Nevertheless, in Quispe-Laime and colleagues' work [1], 38\% of patients did not have septic shock and $28.6 \%$ did not have severe ARDS. Why did the authors use steroids in these patients?

Potential adverse effect from high inspiratory pressure includes: ventilator associated lung injury barotraumas, volutrauma and reduced cardiac output. Furthermore, repetitive overdistention or closing and reopening alveoli can trigger a pulmonary and systemic inflammatory reaction. Quispe-Laime and colleagues may provide information about the plateau pressure levels and potential adverse effect from mechanical ventilation.

The sequential organ failure assessment (SOFA) score is based on six organ categories comprised of the respiratory, cardiovascular, nervous, hepatic, renal, and coagulation systems [5]. The authors may provide the values for each clinical and laboratory parameter included in the SOFA in this group of patients.

The continuous variables are expressed as means \pm standard deviation. It should definitely choose a parametric test if we are sure that our data are sampled from a population that follows a Gaussian distribution. Are continues variables normally distributed?

\section{Conflict of interest statement None.}

\section{References}

1. Quispe-Laime AM, Bracco JD, Barberio PA, Campagne CG, Rolfo VE, Umberger R, Meduri GU (2009) H1N1 influenza A virus-associated acute lung injury: response to combination oseltamivir and prolonged corticosteroid treatment. Intensive Care Med 36:33-41
2. Annane D, Bellissant E, Bollaert PE Briegel J, Confalonieri M, De Gaudio R, Keh D, Kupfer Y, Oppert M, Meduri GU (2009) Corticosteroids in the treatment of severe sepsis and septic shock in adults: a systematic review. JAMA 301:23622375

3. Annane D, Sébille V, Bellissant E, Ger-Inf-05 Study Group (2006) Effect of low doses of corticosteroids in septic shock patients with or without early acute respiratory distress syndrome. Crit Care Med 34:22-30

4. Sprung CL, Annane D, Keh D, Moreno R, Singer M, Freivogel K, Weiss YG, Benbenishty J, Kalenka A, Forst H, Laterre PF, Reinhart K, Cuthbertson BH, Payen D, Briegel J, Corticus study group (2008) Hydrocortisone therapy for patients with septic shock. N Engl J Med 358:111-124

5. Vincent JL, Moreno R, Takala J, Willatts S, De Mendonca A, Bruining H, Reinhart CK, Suter PM, Thijs LG (1996) The SOFA (sepsis-related organ failure assessment) score to describe organ dysfunction/failure: on behalf of the Working Group on Sepsis-Related Problems of the European Society of Intensive Care Medicine. Intensive Care Med 22:707-710

\section{S. A. Ñamendys-Silva (}

Department of Critical Care Medicine, Instituto Nacional de Cancerología, México, Av. San Fernando No. 22,

Col. Sección XVI Delegación Tlalpan, C.P. 14080 Mexico City, DF, Mexico e-mail: tony75ni@msn.com; snamendys@incan.edu.mx

Tel.: +52-5556280400

Fax: +52-5556280449

\section{S. A. Namendys-Silva}

Department of Critical Care Medicine, Instituto Nacional de Ciencias Médicas y Nutrición Salvador Zubirán, Mexico City, Mexico

M. Hernández-Garay Department of Anesthesiology, American British Cowdray Medical Center,

Mexico City, Mexico 